\title{
Erratum in 'Open problems in some competition models' by S. Elaydi and R. Luís
}

To cite this article: (2011) Erratum in 'Open problems in some competition models' by S.

Elaydi and R. Luís, Journal of Difference Equations and Applications, 17:12, 1879-1879, DOI: 10.1080/10236198.2011.585985

To link to this article: https://doi.org/10.1080/10236198.2011.585985

曲 Published online: 18 Nov 2011.

Submit your article to this journal $\pi$

Џll Article views: 189

Q View related articles $\longleftarrow$ 


\section{Erratum in 'Open problems in some competition models' by S. Elaydi and R. Luís \\ (pp. 1873-1877, this issue)}

In [1] the authors present a stability theorem (Theorem 1.1) of the Ricker competition model

$$
\left\{\begin{array}{l}
x_{n+1}=x_{n} e^{K-x_{n}-a y_{n}} \\
y_{n+1}=y_{n} e^{L-y_{n}-b x_{n}} .
\end{array}\right.
$$

The theorem was stated under the erroneous condition $0<a, b<1$. The correct condition, as stated in the full paper [2], is that $a b<1$ and $a, b>0$.

\section{References}

[1] S. Elaydi and R. Luís, Open problems in some competition models, J. Difference Equ. Appl. (First published on: 22 March 2011(iFirst)), 17(12) (2011), pp. 1873-1877 (this issue).

[2] R. Luís, S. Elaydi, and H. Oliveira, Stability of a Ricker-type competition model and the competitive exclusion principle, J. Biol. Dyn., Accepted. 